\title{
Rovatszerkesztői bevezető
}

\section{Fűzi Beatrix, Horváth László}

A pedagógusok mentorálásában rejló lehetőségeket az utóbbi évtizedben tudatosította a szakma. A mentorálás jelentős szerepet tölthet be a következő pedagógusnemzedék felkészitésében és a pályán lévők folyamatos szakmai fejlődésében. Vajon sikerül elérni, hogy a személyre szabott szakmai támogatás pályán tartsa a fiatalokat és csökkentse a súlyos problémákkal küzdő, gyakorló tanárok számát, emelje munkájuk színvonalát? Rovatunk szerzői izelitőt adnak abból, miként válhat a mentortanárok tevékenysége az iskolai müködés szerves részévé. Írásaik felhívják a figyelmet azonban arra is, hogy munkájuk hatékonyságát csökkentik többek közt a szabályozási hiányosságok, a pedagógusok munkaterhei és anyagi megbecsülése közti aránytalanság vagy a pedagógusok saját, belső ellenállása. Még ha jó gyakorlatok bemutatásával szolgálnak is a következő cikkek, több kérdés nyitott maradt: Milyen szabályozási környezet maximalizálhatja a mentortanárok munkájának eredményességét? Hogyan vonhatók be a nehézségekkel küszködő pedagógusok a mentorálási folyamatba? Várjuk Olvasóink véleményét, reflexióit az írásokra és a felvetett kérdésekre!

Kulcsszavak: tanárjelöltek mentorálása, gyakorló tanárok mentorálása, közoktatási mentorálás, mentorálás korlátai

The potential for mentoring teachers has been recognized by the Hungarian profession in the last decade. Mentoring can play a significant role in preparing the next generation of teachers and in the continuous professional development of experienced teachers. Is it possible to get personalized professional support to keep newcomers in schools and to decrease the number of experienced teachers with serious problems, to raise the quality of their work? Our authors demonstrate how the activities of mentor teachers can become an integral part of school operations. However, their articles also point out that the effectiveness of mentor teachers' work is reduced by, among other things, regulatory deficiencies, disproportions between teachers' workload and financial esteem, or mentees' own internal resistance. Even though the articles provide good practices, several questions remain open: What regulatory environment can maximize the effectiveness of mentor teachers' work? How can teachers with difficulties be involved in the mentoring process?

Keywords: mentoring of novice teachers, mentoring of experienced teacher, barriers of effective mentoring

DOI: 10.37205/TEL-hun.2019.3-4.07 